\title{
Adenosine Uptake Sites in Brain: Regional Distribution of Putative Subtypes in Relationship to Adenosine A1-Receptors
}

\author{
Jurgen Deckert, Jean-Claude Bisserbe, ${ }^{\mathrm{a}}$ Ehud Klein, ${ }^{\mathrm{b}}$ and Paul J. Marangos \\ Unit on Neurochemistry, Biological Psychiatry Branch, NIMH, National Institutes of Health, Bethesda, Maryland 20892
}

Adenosine uptake sites have been characterized and localized in guinea pig and pointer dog brain by in vitro autoradiography, using as probes ${ }^{3} \mathrm{H}-$ nitrobenzylthioinosine $\left({ }^{3} \mathrm{H}\right.$ NBI) and the recently available ${ }^{3} \mathrm{H}$-dipyridamole ( $\left.{ }^{3} \mathrm{H}-\mathrm{DPR}\right)$. In guinea pig brain and, to a lesser extent, in pointer dog brain, 3H-DPR was found to label more high-affinity binding sites than ${ }^{3} \mathrm{H}-\mathrm{NBI}$ and $\mathrm{NBI}$ inhibited ${ }^{3} \mathrm{H}$-DPR binding having pseudoHill coefficients smaller than 0.5 . ${ }^{3} \mathrm{H}-\mathrm{DPR}$ and ${ }^{3} \mathrm{H}-\mathrm{NBI}$ labeled brain structures with different intensities in guinea pig brain, as was revealed by quantitative analysis. While the intensity of ${ }^{3} \mathrm{H}$-DPR binding varied about 4-fold in neuron-containing structures, 8-fold differences were observed for ${ }^{3} \mathrm{H}-\mathrm{NBI}$ binding with phylo- and ontogenetically older brain areas such as hypothalamus and various brain stem structures showing relatively higher densities. These findings raise the interesting possibility of adenosine uptake site heterogeneity (NBI-sensitive and insensitive) in guinea pig brain, complementing the well-established adenosine receptor heterogeneity (A1 and A2). As adenosine's neurodepressant effects are believed to be mainly mediated by adenosine A1-receptors, these were localized using ${ }^{3} \mathrm{H}$-cyclohexyladenosine ( ${ }^{3} \mathrm{H}-\mathrm{CHA}$ ) as a ligand probe. In guinea pig brain, the highest receptor densities were seen in hippocampus and claustrum, while only relatively low levels were found in hypothalamus and various brain stem structures. As was previously described for rat brain, major discrepancies in the regional distribution of adenosine A1-receptors and adenosine uptake sites, as labeled by ${ }^{3} \mathrm{H}-\mathrm{NBI}$, were seen in guinea pig brain. These discrepancies were only partly abolished (e.g., in cerebellum) by the use of ${ }^{3} \mathrm{H}$-DPR as an additional ligand probe for adenosine uptake sites. Adenosine uptake site heterogeneity, therefore, probably does not explain the previously described discrepancies in rodent brain between the distribution of adenosine A 1-receptors and uptake sites. Because of the low affinity of ${ }^{3} \mathrm{H}$-DPR for adenosine uptake sites in rat and mouse brain, these species

\footnotetext{
Received June 3, 1987; revised Oct. 13, 1987; accepted Nov. 27, 1987.

J.D. is the recipient of a scholarship from Deutsche Forschungsgemeinschaft (DE-357/1-1). J.-C.B. is supported by a fellowship from Fondation pour l'Etude du Systeme Nerveux Central et Peripherique. We are grateful to J. Unnerstall and $\mathrm{T}$. Insel for providing the ${ }^{3} \mathrm{H}$-microscales and to Miss T. DiBari for preparing the manuscript.

Correspondence should be addressed to Dr. Jurgen Deckert, Universitats-Nervenklinik, Fuchsleinstr. 15, D-8700 Wurzburg, FRG.

a Present address: Service Hospitalier Frederic Joliot, Departement de BiologieC.E.A., 4, Place de General Leclerc, 91406 Orsay, France.

b Present address: Department of Psychiatry, Rambam Medical Center, Haifa 35254 , Israel.

0270-6474/88/072338-12\$02.00/0
}

could not be investigated with this new radioligand probe. In pointer dog brain, as compared to guinea pig brain, a more similar distribution pattern of adenosine A1-receptors and adenosine uptake sites in the brain structures investigated (e.g., hippocampus) could be observed. The situation in guinea pig brain can, therefore, not be universalized to other species. The localization of A1-receptors and uptake sites in many regions of guinea pig and pointer dog brain that receive and modulate sensory input is consistent with the existence of a functional inhibitory adenosinergic neuromodulatory system In these brain areas. The nature of this adenosinergic neuromodulation may be reflected by the relative densities of adenosine receptors and uptake sites.

In recent years, adenosine has been widely accepted as an important neuromodulator (for review, see Dunwiddie, 1985). Its CNS depressant effects are believed to be mediated mainly by one (Al) of 2 ectocellular receptors (Al and A2) coupled to adenylate cyclase systems (van Calker et al., 1979; Londos et al., 1980). Using adenylate cyclase assays, a different pharmacology and localization in brain for these 2 receptors has been demonstrated (Ebersolt et al., 1983; Wojcik and Neff, 1983). On the basis of these adenylate cyclase studies, specific ligands for the adenosine A1-receptor- ${ }^{3} \mathrm{H}$-cyclohexyladenosine $\left({ }^{3} \mathrm{H}\right.$ CHA) (Bruns et al., 1980), ${ }^{3} \mathrm{H}$-phenylisopropyladenosine $\left({ }^{3} \mathrm{H}\right.$ PIA) (Schwabe and Trost, 1980), and, with some restrictions for the adenosine A2-receptor, ${ }^{3} \mathrm{H}$-ethylcarboxamidoadenosine ( ${ }^{3} \mathrm{H}-\mathrm{NECA}$ ) (Yeung and Green, 1984)-have been developed and used for anatomical studies. Adenosine A1-receptors represent the majority of adenosine receptors in areas like cerebellum, superior colliculus, and the CA1 region of hippocampus, while A2-receptors dominate in the olfactory tubercle, caudate putamen, and the mossy fibers of hippocampus (Lewis et al. 1981; Goodman and Snyder, 1982; Lee and Reddington, 1986).

Extracellular concentrations of adenosine are regulated by the rapid transport of adenosine into cells, where it is metabolized either by adenosine kinase or deaminase (for review, see Patel et al., 1984). This transport has been very extensively characterized in mammalian erythrocytes and tumor cell lines, and the existence of nitrobenzylthioinosine (NBI)-sensitive and insensitive transport has been described (Cass and Paterson, 1972; Kolossa and Pfleger 1975; Paterson et al., 1980; Belt, 1983; Plagemann and Wohlhueter, 1984). On the other hand, only a few reports have appeared investigating this transport or uptake in mammalian brain (Huang and Daly, 1974; Bender et al., 1980; Barberis et al., 1981). The existence of rapid, high-affinity uptake in rat brain has been reported (Bender et al., 1980), but no extensive characterization has been undertaken. 
NBI $\left(\left[{ }^{14} \mathrm{C}\right]\right.$ and $\left.\left[{ }^{3} \mathrm{H}\right]\right)$, one of a number of transport inhibitors, was, until recently, the only ligand probe for adenosine uptake sites (Pickard et al., 1973; Jarvis and Young, 1980; Marangos et al., 1982; Hammond and Clanachan, 1984). It labeled, however, only a relatively low number of adenosine uptake sites and, in several rat brain areas, especially in cerebellum and hippocampus with high adenosine receptor density, only few adenosine uptake sites could be visualized (Geiger and Nagy, 1984; Bisserbe et al., 1985), raising doubts about the capability of ${ }^{3} \mathrm{H}-\mathrm{NBI}$ to label all adenosine uptake sites. Similarly, direct measurement of adenosine uptake into guinea pig (and rat) brain slices or synaptosomes (Huang and Daly, 1974; Bender et al., 1981; Phillis and $\mathrm{Wu}, 1983$; Davies and Hambley, 1986; Morgan and Marangos, 1987) and studies of the enhancement of adenosine's effect on cAMP production (Huang and Daly, 1974) and EPSPs (Sanderson and Scholfield, 1986) by adenosine transport inhibitors indicate that, in guinea pig (and probably also in rat) brain, NBI in submicromolar concentrations inhibits only about half of the adenosine uptake inhibited by dipyridamole (DPR), another potent transport inhibitor.

Recently, ${ }^{3} \mathrm{H}-\mathrm{DPR}$ has been available as a ligand probe (Marangos et al., 1985; Bisserbe et al., 1986). While no high-affinity ${ }^{3} \mathrm{H}$-DPR binding sites can be detected in membranes prepared from rat brain, ${ }^{3} \mathrm{H}$-DPR labels about 3 times more adenosine uptake sites than does ${ }^{3} \mathrm{H}-\mathrm{NBI}$ in guinea pig membranes, and NBI inhibits less than $50 \%$ of ${ }^{3} \mathrm{H}$-DPR binding in the nanomolar concentration range, suggesting heterogeneity of adenosine uptake sites in guinea pig brain (Marangos and Deckert, 1987).

Adenosine uptake site heterogeneity could obviously be the reason for the reported mismatches between uptake sites and adenosine A1-receptors in rat brain. As no high-affinity ${ }^{3} \mathrm{H}$-DPR binding sites had been detected in rat brain, we decided to examine this possibility in 3 other species: mouse, guinea pig, and-as an example of a nonrodent mammal-pointer dog. We investigated the biochemical characteristics of ${ }^{3} \mathrm{H}$-DPR binding in brain slices of these 3 species and compared them in the 2 latter ones with the characteristics of ${ }^{3} \mathrm{H}-\mathrm{NBI}$ binding. In autoradiographic studies in guinea pig and pointer dog brain, we visualized the regional distribution of adenosine uptake sites labeled by these 2 probes as compared to adenosine Al-receptors labeled by ${ }^{3} \mathrm{H}-\mathrm{CHA}$, and quantitatively analyzed the relative density of these binding sites in guinea pig brain.

\section{Materials and Methods}

In general, the procedure described by Herkenham and Pert (1982) was applied. Ten male NIH multipurpose guinea pigs (250-350 gm) and 6 male NIH Albino mice (about $30 \mathrm{gm}$ ) were decapitated. Four pointer dogs were anesthetized by pentobarbital $(25 \mathrm{mg} / \mathrm{kg})$ and kept in a respirator; their brain was surgically exposed, and the dogs then killed by an additional injection of pentobarbital $(40 \mathrm{mg} / \mathrm{kg})$ and $\mathrm{KCl}(2 \mathrm{mEq} / \mathrm{kg})$. The brains were immediately removed, frozen in isopentane $\left(-50^{\circ} \mathrm{C}\right)$, and kept at $-70^{\circ} \mathrm{C}$ until further use. For cutting, the brains were fixed onto a brass microtome chuck with cmbedding tissuc (M1 embedding matrix; Lipshaw, Detroit, MI). Twenty-micron sections were cut at $-14^{\circ} \mathrm{C}$ in a Bright-Hacker cryostat, thaw-mounted on gelatin-coated glass slides (Kimble, Toledo, $\mathrm{OH}$ ), and stored at $-70^{\circ} \mathrm{C}$ until they were used in biochemical or autoradiographic experiments.

Biochemical experiments. Slide-mounted brain sections were incubated for 20 (guinea pig) or 30 (pointer dog and mouse) $\mathrm{min}$ in $50 \mathrm{~mm}$ Tris- $\mathrm{HCl}$ buffer, $\mathrm{pH} 7.4$, at room temperature $\left(22^{\circ} \mathrm{C}\right)$ with various concentrations of ${ }^{3} \mathrm{H}-\mathrm{DPR}(110 \mathrm{Ci} / \mathrm{mmol}$; Moravek Biochemicals, Brea, $\mathrm{CA})$. Nonspecific binding was defined in the presence of $50 \mu \mathrm{M}$ DPR (Sigma, St. Louis, MO) and represented 35\% (guinea pig), 20\% (pointer $\mathrm{dog}$ ), or $50 \%$ (mouse) of total binding at $K_{\mathrm{d}} / 2$ concentrations. After the incubation, the slices were rinsed twice for $15 \mathrm{sec}$ (guinea pig), twice for $2 \mathrm{~min}$ (pointer dog), or twice for $4 \mathrm{~min}$ (mouse) in ice-cold incubation buffer. Similarly, brain slices (guinea pig and pointer dog) were incubated

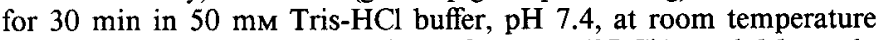
$\left(22^{\circ} \mathrm{C}\right)$, with various concentrations of ${ }^{3} \mathrm{H}-\mathrm{NBI}(37 \mathrm{Ci} / \mathrm{mmol}$; Moravek, Brea, CA). Nonspecific binding was defined in the presence of $5 \mu \mathrm{M}$ NBI (Calbiochem, La Jolla, CA) and represented $25 \%$ (guinea pig) or $35 \%$ (pointer dog) of total binding at about $K_{\mathrm{d}} / 2$ concentrations. After the incubation, the slices were rinsed twice for $1 \mathrm{~min}$ (guinea pig) or twice for $4 \mathrm{~min}$ (pointer dog) in ice-cold incubation buffer. Brain slices were also incubated for $60 \mathrm{~min}$ (guinea pig) or $90 \mathrm{~min}$ (pointer dog) in 50 $\mathrm{mm}$ Tris- $\mathrm{HCl}$ buffer, $\mathrm{pH} 7.4$, containing $1.4 \mathrm{IU}$ adenosine deaminase (from calf intestinal mucosa; Sigma), at room temperature $\left(22^{\circ} \mathrm{C}\right.$ ), with various concentrations of ${ }^{3} \mathrm{H}-\mathrm{CH} \Lambda(25 \mathrm{Ci} / \mathrm{mmol}$; NEN-DuPont, Boston, MA). Nonspecific binding was defined in the presence of $20 \mu \mathrm{M}$ CHA (Calbiochem) and represented 25\% (guinea pig and pointer dog) of total binding at $K_{\mathrm{d}} / 2$ concentrations. After the incubation, the slices were rinsed in ice-cold incubation buffer twice for $15 \mathrm{sec}$ (guinea pig) or twice for $2 \mathrm{~min}$ (pointer $\mathrm{dog}$ ). In careful preliminary experiments, the respective incubation and rinsing times had been found to be the shortest to achieve saturation of binding and the optimal nonspecific: total binding ratio without loss of specific binding. After rinsing, the slices were wiped off the slides with Whatman GF/B filters, put in scintillation vials with $10 \mathrm{ml}$ Beckman Ready-Solv, and counted at $40 \%$ efficiency in a Beckman LS 5800 scintillation spectrophotometer. To determine the protein content, adjacent slide-mounted sections were dried at room temperature overnight, then scraped off the slides and

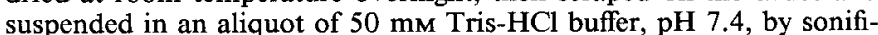
cation. Protein was measured using the Biorad reagent (Bradford, 1976).

Autoradiographic experiments. Adjacent slide-mounted sections of 3 guinea pig and 2 pointer dog brains were incubaled with $3.5 \mathrm{~nm}$ (guinea pig ) or $2.5 \mathrm{~nm}$ (pointer dog) ${ }^{3} \mathrm{H}-\mathrm{DPR}, 0.6 \mathrm{~nm}$ (guinea pig) or $0.4 \mathrm{~nm}$ (pointer dog) ${ }^{3} \mathrm{H}-\mathrm{NBI}$, and $3.5 \mathrm{~nm}$ (guinea pig) or $5 \mathrm{~nm}$ (pointer dog) ${ }^{3} \mathrm{H}-\mathrm{CHA}$ under the respective conditions described above. Nonspecific binding under these conditions was quite homogeneous among gray matter structures and represented the above-mentioned fractions of total binding. Following the incubation and rinses, the slides were put on racks, dried under a stream of cold, filtered air, and placed in apposition to LKB ultrofilm, as first described hy Penney et al. (1981). After 2-4 ( $\left.{ }^{3} \mathrm{H}-\mathrm{DPR}\right)$ or $4-8\left({ }^{3} \mathrm{H}-\mathrm{NBI}\right.$ and $\left.{ }^{3} \mathrm{H}-\mathrm{CHA}\right)$ weeks of exposure, the films were developed in Kodak D-19 $\left(4 \mathrm{~min}\right.$ at $\left.22^{\circ} \mathrm{C}\right)$, fixed in Kodak Rapid Fixcr ( $3 \mathrm{~min})$, then rinsed for $30 \mathrm{~min}$ under running tap water, cleaned with deionized water, and dried. The autoradiograms were screened and optical density measurements were performed using the computer image-processing system described by Gochee el al. (1980). Optical density values were transformed into $\mathrm{fmol} / \mathrm{mg}$ of dry tissue with Amersham ${ }^{3} \mathrm{H}$-microscale standards. Identifications of the brain microregions were made with aid of adjacent thionin-stained sections, using as references the atlases of Paxinos and Watson (1982), Luparello (1967), and Singer (1962.)

\section{Results}

Biochemical properties of ${ }^{3} \mathrm{H}-\mathrm{DPR},{ }^{3} \mathrm{H}-\mathrm{NBI}$, and ${ }^{3} \mathrm{H}-\mathrm{CHA}$ binding to brain slices

The affinity of ${ }^{3} \mathrm{H}-\mathrm{DPR}$ binding varied widely from species to species. Employing an isotopic dilution $(11 \mathrm{Ci} / \mathrm{mmol})$ and investigating a concentration range from 2 to $250 \mathrm{nM}(n=6)$, we could only obtain approximate estimates of the kinetic parameters $\left(K_{\mathrm{d}}\right.$ between 90 and $\left.150 \mathrm{nM}\right)$ in mouse forebrain. This and the high nonspecific binding prevented us from undertaking a thorough investigation of this binding site. However, ${ }^{3} \mathrm{H}-\mathrm{DPR}$ bound with sufficiently high affinity to guinea pig forebrain $\left(K_{\mathrm{d}}\right.$ about $10 \mathrm{nM}$ ) and with even higher affinity to pointer dog prefrontal cortex slices ( $K_{\mathrm{d}}$ about $1 \mathrm{nM}$ ) (Fig. 1). In pharmacological experiments, DPR itself displaced ${ }^{3} \mathrm{H}-\mathrm{DPR}$ binding in guinea pig brain and pointer dog brain slices, with inhibition constants close to its own dissociation constants and pseudo-Hill coefficients of about 1 (1.2 and 0.8) (Fig. 2). CHA was about 1000fold less potent with inhibition constants in the high-nanomolar or low-micromolar range (Fig. 2). NBI inhibited ${ }^{3} \mathrm{H}$-DPR binding, with $K_{\mathrm{i}} \mathrm{s}$ of about 20 - (pointer dog) to 200-fold (guinea pig) 

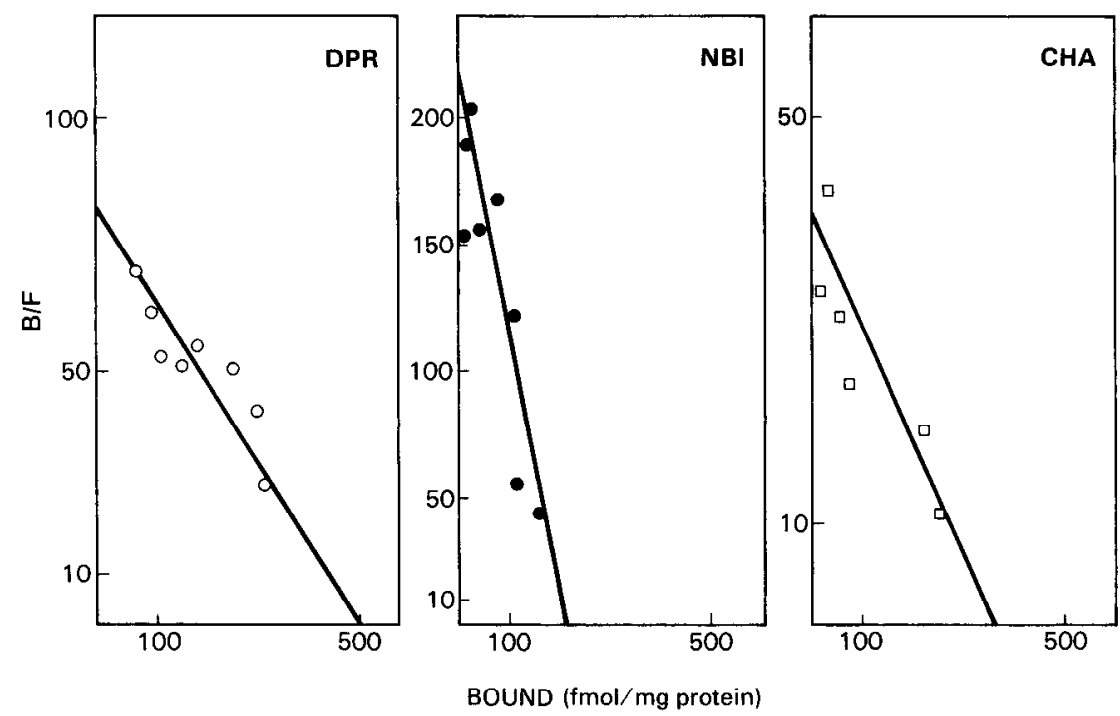

Figure 1. Scatchard analysis of ${ }^{3} \mathrm{H}-\mathrm{DPR},{ }^{3} \mathrm{H}-\mathrm{NBI}$, and ${ }^{3} \mathrm{H}-\mathrm{CHA}$ binding to forebrain slices in guinea pig brain. Representative experiments are shown. The obtained estimates of the kinetic parameters $\left(K_{\mathrm{d}}\right.$ in $\mathrm{nM}$ and $B_{\max }$ in $\mathrm{fmol} / \mathrm{mg}$ protein) of high-affinity ${ }^{3} \mathrm{H}$-ligand binding in these representative experiments were, for ${ }^{3} \mathrm{H}-\mathrm{DPR}, 5.5 \mathrm{nM}$ and $500 \mathrm{fmol} / \mathrm{mg}$ protein; for ${ }^{3} \mathrm{H}-\mathrm{NBI}, 0.8 \mathrm{nM}$ and $190 \mathrm{fmol} / \mathrm{mg} \mathrm{protein}$; and for ${ }^{3} \mathrm{H}-\mathrm{CHA}$, $7 \mathrm{nM}$ and $350 \mathrm{fmol} / \mathrm{mg}$ protein. Similar results were obtained with prefrontal cortex slices in pointer dog brain; e.g., for ${ }^{3} \mathrm{H}-\mathrm{DPR}, 1.5 \mathrm{nM}$ and 90 $\mathrm{fmol} / \mathrm{mg}$ protein; for ${ }^{3} \mathrm{H}-\mathrm{NBI}, 0.7 \mathrm{nM}$ and $40 \mathrm{fmol} / \mathrm{mg}$ protein; and for ${ }^{3} \mathrm{H}-\mathrm{CHA}, 20 \mathrm{nM}$ and $220 \mathrm{fmol} / \mathrm{mg}$ protein. These experiments were repeated at least 3 times, with very similar results. The concentration ranges of ${ }^{3} \mathrm{H}$-ligand were $0.1-10 \mathrm{~nm}$ (pointer dog) and $0.5-40 \mathrm{nM}$ (guinea pig) for ${ }^{3} \mathrm{H}$ DPR, 0.04-4 nM for ${ }^{3} \mathrm{H}$-NBI (under these conditions, the possibility of an additional lower-affinity site could not be excluded), and $0.4-44$ nM for ${ }^{3} \mathrm{H}-\mathrm{CHA}$.

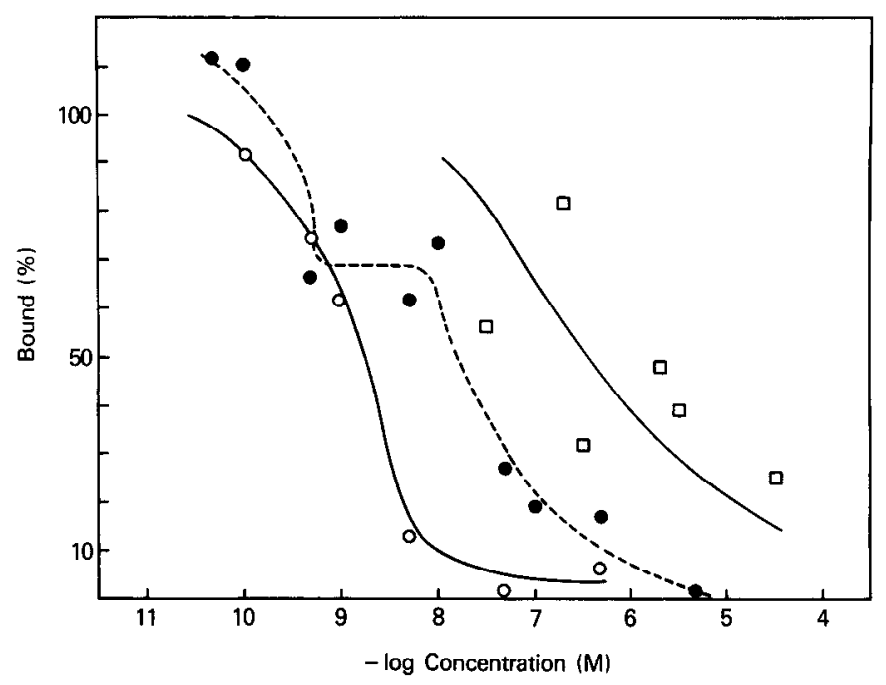

Figure 2. Displacement of ${ }^{3} \mathrm{H}-\mathrm{DPR}$ binding to adjacent prefrontal cortical slices in pointer dog brain by DPR (O), NBI (e), and CHA (D). A representative experiment is shown. The dashed line of the NBI displacement curve indicates that the inhibition curve was fitted according to a 2-site model, but that a fit according to a cooperative model would have been similarly justified. The pseudo-Hill coefficient $\left(n_{\mathrm{H}}\right)$ for the inhibition by NBI was 0.4 , the inhibition constant $\left(K_{\mathrm{i}}\right)$ was calculated as $4.5 \mathrm{nM}$, and as $K_{\mathrm{i}}$ estimate for the high-affinity component, $0.2 \mathrm{nM}$ was obtained. Inhibition constants $\left(K_{i}\right)$ for DPR and CHA were 0.6 and $340 \mathrm{~nm}$ respectively. Similar results were obtained with forebrain slices in guinea pig brain, e.g., for NBI, $0.3\left(n_{\mathrm{H}}\right), 1500 \mathrm{nM}\left(K_{\mathrm{i}}\right)$, and $0.7 \mathrm{nM}$ ( $K_{\mathrm{i}}$ estimate of high-affinity component), for DPR, $7 \mathrm{nM}\left(K_{\mathrm{i}}\right)$, and for CHA, $5200 \mathrm{~nm}\left(K_{\mathrm{i}}\right)$. These experiments were repcated at lcast 3 times, with very similar results. Five to 10 concentrations of inhibitor were applied and the concentration of ${ }^{3} \mathrm{H}-\mathrm{DPR}$ was $3.5 \mathrm{nM}$ in guinea pig and $2.5 \mathrm{nM}$ in pointer dog. higher than its own dissociation constant (Fig. 2); pseudo-Hill coefficients were lower than 1 -about 0.5 (pointer dog) and 0.3 (guinea pig). $K_{\mathrm{i}}$ estimates for the high-affinity component, from curves drawn though the experimental points according to a 2 site model, were very close to $K_{\mathrm{d}} \mathrm{s}$ of high-affinity ${ }^{3} \mathrm{H}-\mathrm{NBI}$ binding (Figs. 1, 2). Accordingly, the number of binding sites with $K_{\mathrm{d}} \mathrm{s}$ about $0.5 \mathrm{nM}$ labeled by ${ }^{3} \mathrm{H}-\mathrm{NBI}$ was smaller than the number of high-affinity ${ }^{3} \mathrm{H}-\mathrm{DPR}$ binding sites (Fig. 1). ${ }^{3} \mathrm{H}-\mathrm{CHA}$ binding experiments demonstrated high-affinity binding, in the 2 investigated species, with very similar characteristics (Fig. 1).

\section{Localization of ${ }^{3} \mathrm{H}-\mathrm{DPR},{ }^{3} \mathrm{H}-\mathrm{NBI}$, and ${ }^{3} \mathrm{H}-\mathrm{CHA}$ binding sites}

The gross patterns of ${ }^{3} \mathrm{H}-\mathrm{DPR}$ and ${ }^{3} \mathrm{H}-\mathrm{NBI}$ binding in guinea pig brain were rather similar (Figs. 3-6). However, the relative densities varied considerably from area to area (Table 1 ).

The highest ${ }^{3} \mathrm{H}$-DPR and ${ }^{3} \mathrm{H}-\mathrm{NBI}$ binding site densities were observed in non-neuronal structures. Both ligands labeled both the brain arteries $(147 \pm 19$ and $181 \pm 10 \mathrm{fmol} / \mathrm{mg}$, respectively) and choroid plexus (111 \pm 10 and $134 \pm 10 \mathrm{fmol} / \mathrm{mg}$, respectively) very intensively. Very high ${ }^{3} \mathrm{H}-\mathrm{DPR}$ binding densities were observed in the ependymal cell lining of the lateral ventricles $(195 \pm 20 \mathrm{fmol} / \mathrm{mg})$, while relatively low ${ }^{3} \mathrm{H}-\mathrm{NBI}$ binding ( $57 \pm 2 \mathrm{fmol} / \mathrm{mg}$ ) was found there.

Among neuron-containing structures, 7-fold differences in density were measured for ${ }^{3} \mathrm{H}-\mathrm{NBI}$ (e.g., area postrema: $155 \pm$ $28 \mathrm{fmol} / \mathrm{mg}$; globus pallidus: $23 \pm 2 \mathrm{fmol} / \mathrm{mg}$ ), but less than 4-fold density differences for ${ }^{3} \mathrm{H}-\mathrm{DPR}$ (e.g., area postrema: 95 $\pm 10 \mathrm{fmol} / \mathrm{mg}$; globus pallidus: $29 \pm 2 \mathrm{fmol} / \mathrm{mg}$ ). ${ }^{3} \mathrm{H}-\mathrm{DPR}$ binding was thus relatively homogeneous, e.g., superficial layers (1-4) of parietal cortex (SL-PC): $78 \pm 4 \mathrm{fmol} / \mathrm{mg}$; medial preoptic area (MPO): $66 \pm 7 \mathrm{fmol} / \mathrm{mg}$; molecular layer of cerebellum 

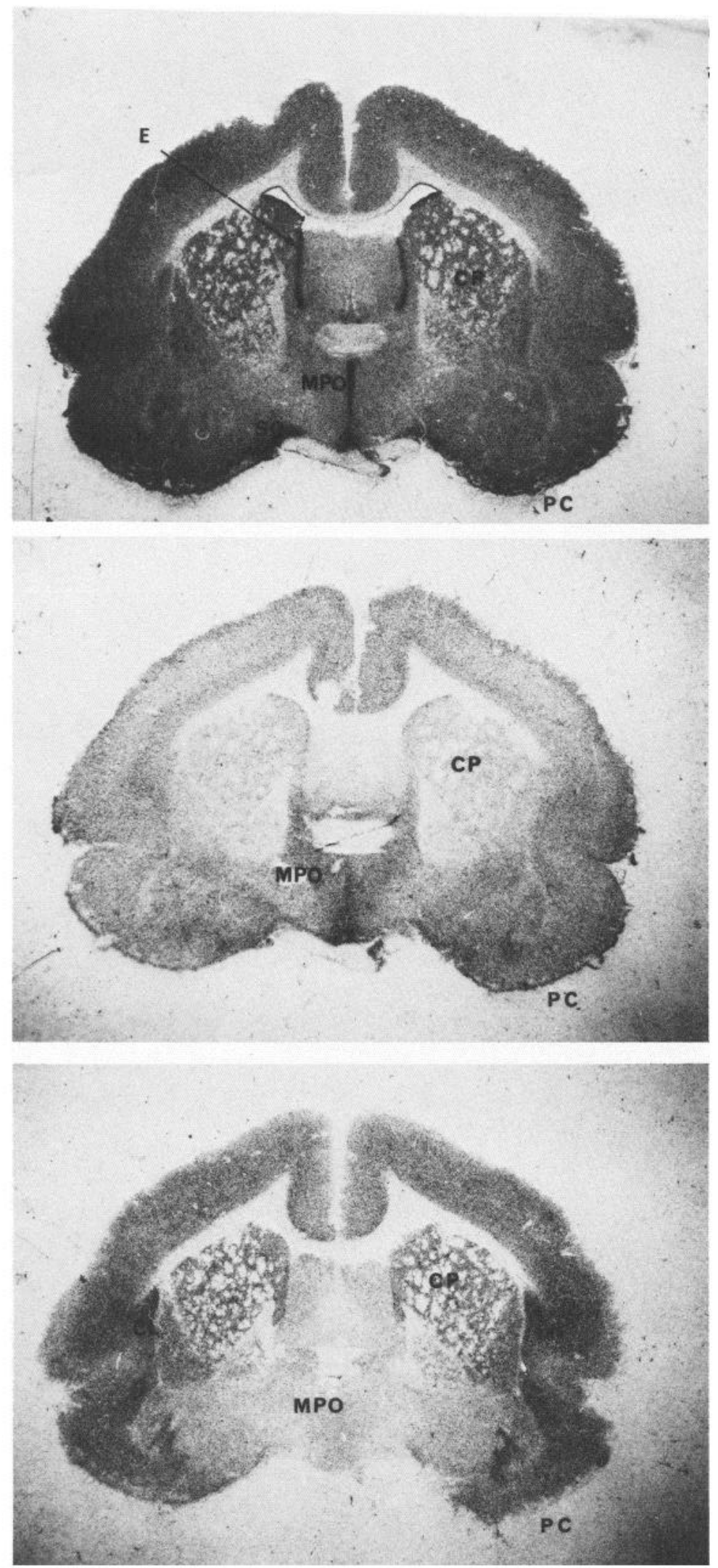

Figure 3. Localization of ${ }^{3} \mathrm{H}-\mathrm{DPR}$ (top), ${ }^{3} \mathrm{H}-\mathrm{NBI}$ (middle), and ${ }^{3} \mathrm{H}-\mathrm{CHA}$ (bottom) binding sites in adjacent coronal sections in the plane of the prefrontal cortex of a guinea pig brain. Note that the highest binding density is for ${ }^{3} \mathrm{H}-\mathrm{DPR}$ in the ependyma $(E)$, for ${ }^{3} \mathrm{H}-$ NBI in the medial preoptic area $(M P O)$, and for ${ }^{3} \mathrm{H}-\mathrm{CHA}$ in the claustrum $(C L)$. Other structures shown are caudate putamen $(C P)$, pyriform cortex $(P C)$ and supraoptic nucleus $(S O)$. For better comparison, the images in Figures 3-6 were placed in apposition to the same film and exposed for 4 weeks. Ligand concentrations were $3.5 \mathrm{nM}$ for ${ }^{3} \mathrm{H}$-DPR and ${ }^{3} \mathrm{H}-\mathrm{CHA}$ and $0.6 \mathrm{nM}$ for ${ }^{3} \mathrm{H}-\mathrm{NBI}$.
(ML-C): $66 \pm 4 \mathrm{fmol} / \mathrm{mg}$; inferior olivary complex (IOC): 64 $\pm 4 \mathrm{fmol} / \mathrm{mg}$. The corresponding ${ }^{3} \mathrm{H}-\mathrm{NBI}$ densities in these representative brain areas were, for SL-PC, $48 \pm 3 \mathrm{fmol} / \mathrm{mg}$; MPO, $90 \pm 6 \mathrm{fmol} / \mathrm{mg}$; ML-C, $37 \pm 3 \mathrm{fmol} / \mathrm{mg}$; and IOC, 71 $\pm 4 \mathrm{fmol} / \mathrm{mg}$. To obtain an impression of the relative densities of the 2 binding sites in basal and cortical brain structures, the ratios MPO:SL-PC and IOC:ML-C were calculated. While they were close to 1 for ${ }^{3} \mathrm{H}-\mathrm{DPR}$ (MPO:SL-PC, 0.85; IOC:ML-C, 1), 
Table 1. Regional adenosine uptake site and adenosine Al-receptor density in guinea pig brain

\begin{tabular}{llll} 
& DPR & NBI & CHA \\
\hline Pyriform cortex & $4+$ & $3+$ & $3+$ \\
Nucleus accumbens & $3+$ & $2+$ & $3+$ \\
Caudate-putamen & $3-$ & $2+$ & $3-$ \\
Globus pallidus & $2-$ & $1+$ & $1+$ \\
Claustrum & $3-$ & $3-$ & $5-$ \\
Septum, lateral & $2+$ & $2-$ & $2+$ \\
Bed nuclei striae terminalis & $3-$ & $3+$ & $2-$ \\
Corpus callosum & $1+$ & $1-$ & $1+$ \\
Ependyma & $5+$ & $3-$ & $2-$ \\
Choroidea & $5-$ & $5-$ & N.D.
\end{tabular}

Hypothalamic structures

Anterior

medial preoptic area

supraoptic nucleus

ant. hypothal. nuclei

Medial

med. hypothal. nuclei

Posterior

post. hypothal. nuclei mammillary bodies

Thalamus

Periventricular nucleus

Paratenial nucleus

Anterior thalamic nuclei

Medial thalamic nuclei (incl. reuniens, rhomboideus, gelatinosus)

Ventrolateral thalamic nuclei

Amygdala

Central

Lateral

Hippocampus

Stratum oriens of $\mathrm{CA} 1$

Pyramidal cell layer of CA1

Stratum radiatum of $\mathrm{CA} 1$

Molecular layer of DG

Granular cell layer of DG

Polymorph cell layer DG

Parietal cortex

$$
\text { Superficial }(1-4)
$$

Deep (5/6)

Habenula

Central gray

Geniculate bodies

Dorsolateral

Ventromedial

Substantia nigra

Interpeduncular nucleus

Entorhinal cortex

Superior colliculus

Superficial gray

Optical layer

Intermediate and deep gray

Dorsal raphe

Median raphe

Pontine nuclei

Inferior colliculus

$3+\quad 4-\quad 3-$

$\begin{array}{lll}3- & 3- & 3- \\ 3- & 2+ & 3+\end{array}$

\begin{tabular}{|c|c|c|c|}
\hline & & & Cochlear nuclei \\
\hline $3+$ & $4+$ & $2-$ & Dorsal \\
\hline $5-$ & $3+$ & $3-$ & Ventral \\
\hline $3-$ & $3+$ & $2-$ & $\begin{array}{l}\text { Nucleus tractus solitarii, caudal } \\
\text { Nucleus nervi hypoglossi, caudal }\end{array}$ \\
\hline $3+$ & $3+$ & $2-$ & Area postrema \\
\hline $3+$ & $4-$ & $2-$ & $\begin{array}{l}\text { Nucleus spinalis nervi trigemini } \\
\text { Inferior olivary complex }\end{array}$ \\
\hline $3-$ & $3+$ & $2-$ & $\begin{array}{l}\text { Pyramidal tract } \\
\text { Arteria basilaris }\end{array}$ \\
\hline
\end{tabular}

$3+$
Table 1. Continued

DPR

NBI

CHA

Dorsal tegmental area

Laterodorsal nuclei

Locus cocruleus

Dorsal parabrachial nucleus

Ventral parabrachial nucleus

Nucleus vestibularis, medial

Cerebellum

Molecular layer

Purkinje cell layer

Granular cell layer

Lateral cerebellar nucleus

White matter

Adjacent sections of 3 guinea pig brains were incubated with $3.5 \mathrm{~nm}^{3} \mathrm{H}-\mathrm{DPR}, 0.6$ $\mathrm{nm}{ }^{3} \mathrm{H}-\mathrm{NBI}$, or $3.5 \mathrm{~nm}{ }^{3} \mathrm{H}-\mathrm{CHA}$, as described in text. The means of the obtained $\mathrm{fmol} / \mathrm{mg}$ dry tissue values were grouped into 5 different ranges. These ranges were, for ${ }^{3} \mathrm{H}-\mathrm{DPR}$ and ${ }^{3} \mathrm{H}-\mathrm{NBI}: 1,0-25 \mathrm{fmol} / \mathrm{mg} ; 2,25-50 \mathrm{fmol} / \mathrm{mg} ; 3,50-75 \mathrm{fmol} /$ $\mathrm{mg} ; 4,75-100 \mathrm{fmol} / \mathrm{mg} ; 5,100-200 \mathrm{fmol} / \mathrm{mg}$; and for ${ }^{3} \mathrm{H}-\mathrm{CHA}: 1,0-40 \mathrm{fmol} / \mathrm{mg}$; $2,40-80 \mathrm{fmol} / \mathrm{mg} ; 3,80-120 \mathrm{fmol} / \mathrm{mg} ; 4,120-160 \mathrm{fmol} / \mathrm{mg} ; 5,160-240 \mathrm{fmol} /$ $\mathrm{mg} ;+/-$ indicate if the value is in the upper/lower half of the above ranges. The SEM of gray matter structures (6-30 measurements/structure from at least 2 different brains) were below $25 \%$. N.D., not detected.

they approached values of about 2 for ${ }^{3} \mathrm{H}-\mathrm{NBI}$ (MPO:SL-C, 1.9; IOC:ML-C, 1.9).

${ }^{3} \mathrm{H}-\mathrm{CHA}$ binding sites in guinea pig brain were found in neuron-containing brain structures (Fig. 3-6). The relative densities in various brain structures differed widely from those obtained for ${ }^{3} \mathrm{H}-\mathrm{DPR}$ and even more so from those measured for ${ }^{3} \mathrm{H}$ NBI.

No specific ${ }^{3} \mathrm{H}-\mathrm{CHA}$ binding could be detected in non-neuronal structures such as brain arteries or choroid plexus, and only very low specific binding, not much different from that observed in some white matter structures, was seen in the ependymal cell lining of the lateral ventricles $(40 \pm 6 \mathrm{fmol} / \mathrm{mg})$.

The highest ${ }^{3} \mathrm{H}-\mathrm{CHA}$ binding densities were thus observed in neuron-containing structures (hippocampus and claustrum), with a 20 -fold range in density (e.g., stratum radiatum: $193 \pm 2 \mathrm{fmol} /$ $\mathrm{mg}$; and nucleus vestibularis medialis: $10 \pm 2 \mathrm{fmol} / \mathrm{mg}$ ). ${ }^{3} \mathrm{H}-$ CHA binding was thus the most heterogeneous, e.g., SL-PC: $131 \pm 11 \mathrm{fmol} / \mathrm{mg}$; MPO: $49 \pm 8 \mathrm{fmol} / \mathrm{mg}$; ML-C: $89 \pm 10$ $\mathrm{fmol} / \mathrm{mg}$; and IOC: $25 \pm 2 \mathrm{fmol} / \mathrm{mg}$; and relatively more binding was seen in cortical than in basal brain structures (MPO:SL-C, 0.4; IOC:ML-C, 0.3).

In pointer dog, binding sites for ${ }^{3} \mathrm{H}-\mathrm{CHA},{ }^{3} \mathrm{H}-\mathrm{DPR}$, and ${ }^{3} \mathrm{H}-$ NBI wcre investigated in neuron-containing brain structures (Figs. 7, 8). Similar patterns of uptake sites and adenosine A1receptors were observed in cerebellum (high in molecular layer and low in granular cell layer) and, as opposed to guinea pig brain, also in hippocampus (relatively high uptake and receptor density in Ammon's horn and dentate gyrus). 

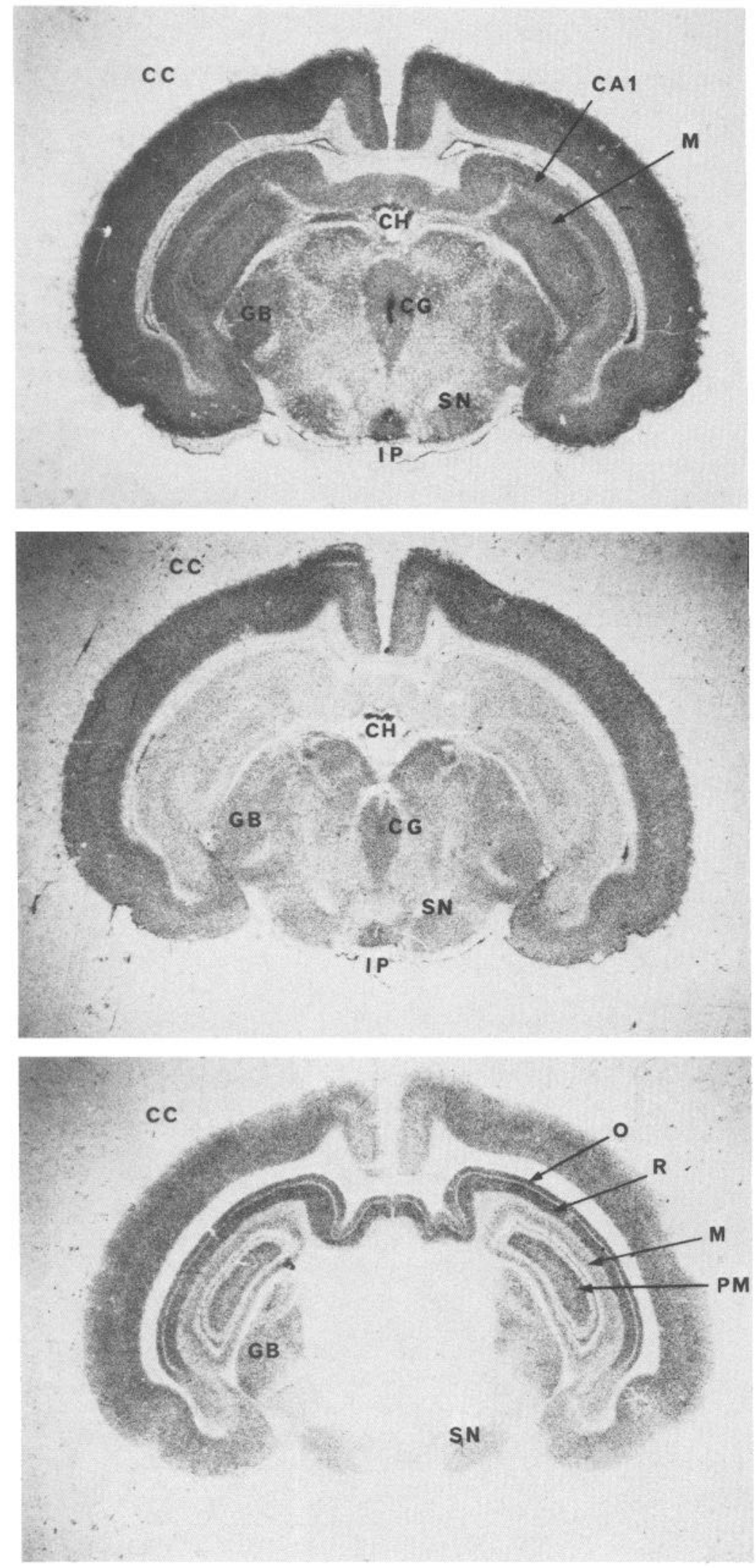

Figure 4. Localization of ${ }^{3} \mathrm{H}-\mathrm{DPR}$ (top), ${ }^{3} \mathrm{H}-\mathrm{NBI}$ (middle), and ${ }^{3} \mathrm{H}-\mathrm{CHA}$ (bottom) binding sites in adjacent coronal sections in the plane of the hippocampus of a guinea pig brain. Note that the highest binding density is for ${ }^{3} \mathrm{H}-\mathrm{DPR}$ and ${ }^{3} \mathrm{H}-\mathrm{NBI}$ in the choroid plexus $(\mathrm{CH})$, while the highest ${ }^{3} \mathrm{H}-\mathrm{CHA}$ binding is found in various layers of the hippocampus (stratum oriens, $O$; stratum radiatum, $R$; molecular layer, $M$; polymorph layer, $P M$ ). Also striking is the rather empty appearance of the hippocampus compared with various midbrain structures (central gray, $C G$; geniculate bodies, $G B$; substantia nigra, $S N$; and interpeduncular nucleus, $I P$ ) when labeled with ${ }^{3} \mathrm{H}-\mathrm{NBI}$, as opposed to the more homogeneous distribution of ${ }^{3} \mathrm{H}$-DPR binding sites in midbrain and hippocampus (CA1 region of hippocampus, $C A I$ ). Slightly different from that of the 2 other ligand probes is the distribution of ${ }^{3} \mathrm{H}-\mathrm{DPR}$ binding in cerebral cortex $(C C)$, with the superficial layers denser than the deeper layers. 

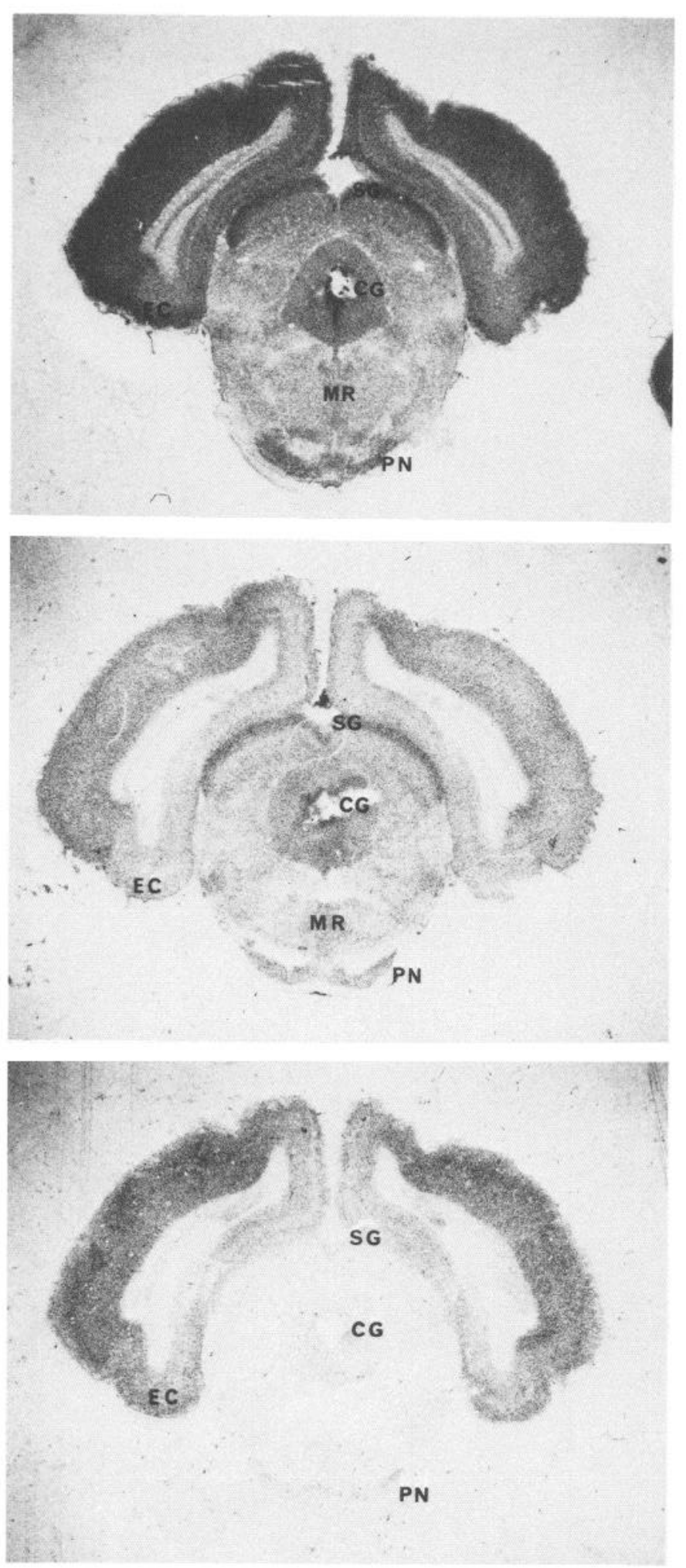

Figure 5. Localization of ${ }^{3} \mathrm{H}-\mathrm{DPR}$ (top), ${ }^{3} \mathrm{H}-\mathrm{NBI}$ (middle), and ${ }^{3} \mathrm{H}-$ CHA (bottom) binding sites in adjacent coronal sections in the plane of the superior colliculus of a guinea pig brain. Similar binding site densities for all 3 ligand probes are seen in cerebral cortical structures like the entorhinal cortex $(E C)$. But, again, much less ${ }^{3} \mathrm{H}-\mathrm{CHA}$ binding is seen in midbrain structures like the superficial gray of the superior colliculus $(S G)$, central gray $(C G)$, median raphe $(M R)$, and pons nuclei $(P N)$.

\section{Discussion}

In guinea pig brain homogenates, ${ }^{3} \mathrm{H}-\mathrm{DPR}$ binding has been pharmacologically characterized as binding to adenosine uptake sites, with adenosine transport inhibitors such as DPR, Hexobendine, and Dilazep demonstrating nanomolar, and adenosine receptor ligands like CHA and 1,3-diethylphenylxanthine showing micromolar potencies in displacing ${ }^{3} \mathrm{H}-\mathrm{DPR}$ binding (Marangos and Deckert, 1987). In good agreement with these membrane binding data are our findings in guinea pig forebrain and pointer dog prefrontal cortex slices that DPR itself inhibits ${ }^{3} \mathrm{H}$ DPR binding, with inhibition constants in the nanomolar range, and of CHA, with inhibition constants in the micromolar range. Further evidence that ${ }^{3} \mathrm{H}-\mathrm{DPR}$ in fact binds to adenosine uptake sites is the observed species differences. The low-affinity binding of ${ }^{3} \mathrm{H}-\mathrm{DPR}$ in rat (Marangos and Deckert, 1987) and mouse brain, and the high-affinity binding in brains of guinea pig and pointer dog correspond well to the potencies of DPR in displacing ${ }^{3} \mathrm{H}-\mathrm{NBI}$ binding in these animals (Hammond and Clanachan, 1985; Verma and Marangos, 1985).

Also in good agreement with membrane binding data (Marangos and Deckert, 1987) is the finding that NBI inhibits ${ }^{3} \mathrm{H}-$ DPR binding in a biphasic manner. In guinea pig, micromolar concentrations are necessary to displace more than $40 \%$ of ${ }^{3} \mathrm{H}$ DPR binding. A high- and low-affinity component of this inhibition can be differentiated and the estimated inhibition constant of the high-affinity component (about $0.5 \mathrm{~nm}$ ) was similar to the dissociation constant of ${ }^{3} \mathrm{H}-\mathrm{NBI}$ binding $(0.8 \mathrm{~nm})$. This indicates that ${ }^{3} \mathrm{H}-\mathrm{NBI}$ binding represents the subpopulation of ${ }^{3} \mathrm{H}$-DPR binding sites that is inhibited by NBI with subnanomolar affinity. NBI has been shown by several groups to inhibit adenosine uptake in guinea pig brain by less than $50 \%$, while DPR inhibits practically all of it (Huang and Daly, 1974; Phillis and Wu, 1983; Davies and Hambley, 1986; Morgan and Marangos, 1987). The good correlation between these functional data and the binding data obtained in brain membranes and brain slices suggests the use of ${ }^{3} \mathrm{H}-\mathrm{NBI}$ as a ligand probe for NBI-sensitive, and ${ }^{3} \mathrm{H}-\mathrm{DPR}$ as a ligand probe for NBI-sensitive, as well as NBI-insensitive, uptake sites in guinea pig brain.

The quantitative autoradiographic studies in guinea pig brain indicate that NBI-sensitive adenosine uptake sites, as labeled by ${ }^{3} \mathrm{H}-\mathrm{NBI}$ represent a varying fraction of the population of adenosine uptake sites labeled by ${ }^{3} \mathrm{H}-\mathrm{DPR}$. In non-neuronal structures, numerous NBI-sensitive uptake sites seem to be present in arteries and choroid plexus, but only relatively few in the ependymal cells lining the ventricles. In neuron-containing brain regions, their density seems to be relatively higher in basal brain areas, such as hypothalamic structures and certain brain stem nuclei, than in cortical areas, such as the superficial layers of cerebral cortex and molecular and Purkinje cell layer of cerebellum, and also some hippocampal layers. This distribution is in good agreement with the previously described localization of ${ }^{3} \mathrm{H}-\mathrm{NBI}$ binding sites in autoradiographic studies in rat brain (Geiger and Nagy, 1984; Bisserbe et al., 1985) and in membrane binding studies in guinea pig and pig brain (Hammond and Clanachan, 1983; Kalaria and Harik, 1986a). On the other hand, this would suggest that NBI-insensitive uptake sites are relatively more numerous in these cortical brain regions, which are ontologically and phylogenetically younger. This distribution pattern complements the above finding that ${ }^{3} \mathrm{H}-\mathrm{DPR}$ is a better ligand probe for adenosine uptake sites in man (unpublished observations), dog, and guinea pig than in mouse or rat. This 

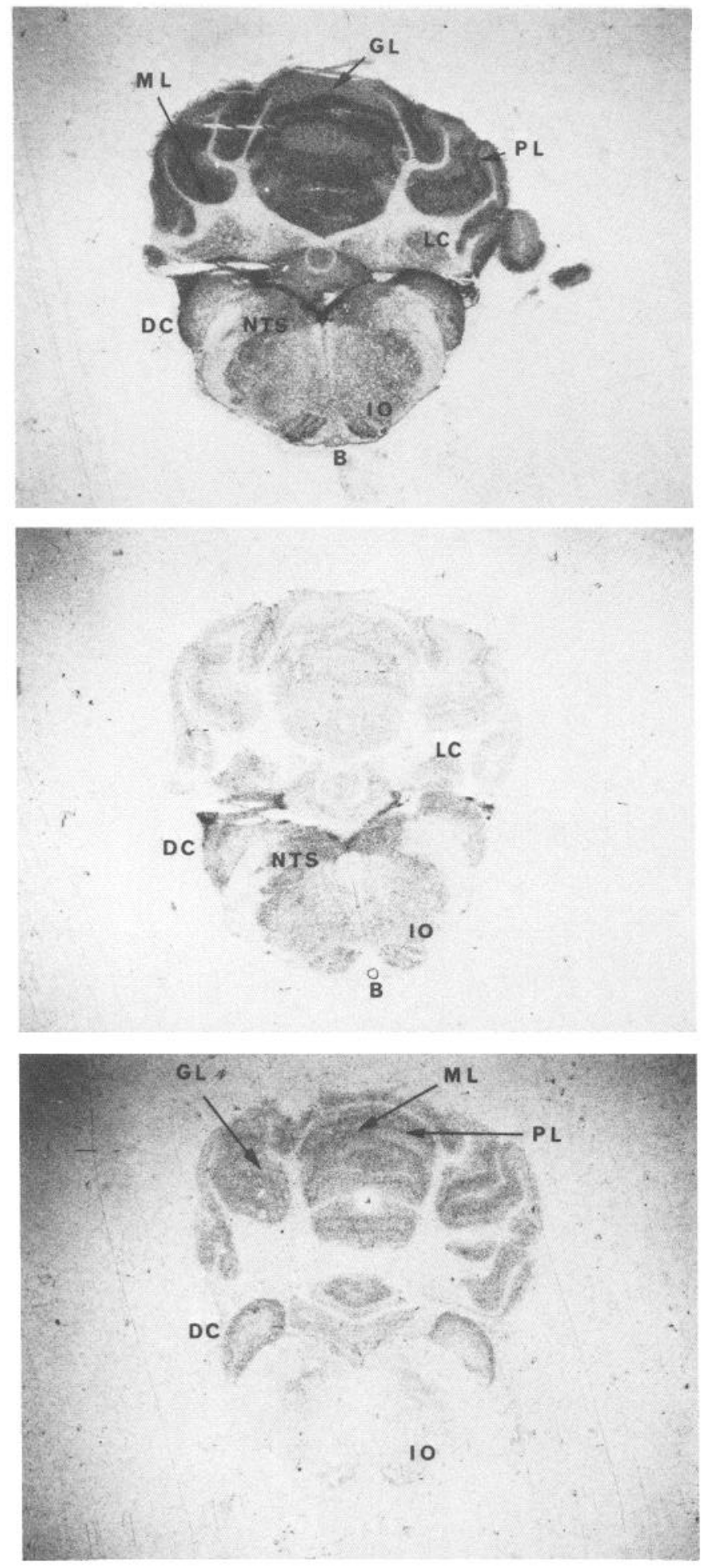

Figure 6. Localization of ${ }^{3} \mathrm{H}-\mathrm{DPR}$ (top), ${ }^{3} \mathrm{H}-\mathrm{NBI}$ (middle), and ${ }^{3} \mathrm{H}-$ CHA (bottom) binding sites in adjacent coronal sections in the plane of ihe cerebellum of a guinea pig brain. Striking pattern differences are seen here in the distribution of the 3 binding sites. The most homogeneous distribution is seen for ${ }^{3} \mathrm{H}-\mathrm{DPR}$, with equally high binding in some cerebellar layers and brain stem structures. ${ }^{3} \mathrm{H}-\mathrm{NBI}$ demonstrates much higher binding in brain stem structures, especially arteria basilaris $(B)$, while only low and rather homogeneous binding is seen throughout the cerebellum. In contrast, high ${ }^{3} \mathrm{H}-\mathrm{CHA}$ binding is seen in the cerebellum and only minimal binding in the brain stem, with the exception of the dorsal cochlear nucleus $(D C)$, which is labeled by all 3 ligands. The distributions of ${ }^{3} \mathrm{H}-\mathrm{DPR}$ and ${ }^{3} \mathrm{H}-\mathrm{CHA}$ binding sites are thus quite interpretation of our data thus would predict a higher ratio of NBI-sensitive adenosine uptake in guinea pig hypothalamus than in cerebellum, and a greater potency of dipyridamole in inhibiting adenosine uptake in man, dog, and guinea pig than in mouse or rat brain. In fact, DPR has already been demonstrated to be more potent in guinea pig than in rat in in vivo studies (Stafford, 1966) and in adenosine uptake studies in erythrocytes (Kolossa and Pfleger, 1975) and brain (Davies and Hambley, 1983; Morgan and Marangos, 1987).

Although our studies strongly suggest the heterogeneity of adenosine uptake sites in guinea pig brain, they do not permit any conclusions to be made concerning its molecular basis, e.g., 2 conformational states (Hammond and Clanachan, 1985), or a functional dimer (Jarvis and Young, 1981) with 2 different subunits or 2 completely separate uptake sites; nor do they allow any conclusions on the cellular (neuronal or glial) or subcellular (plasma, mitochondrial, or nuclear membrane) localization of the 2 suggested subtypes.

A previous autoradiographic study in rat brain (Bisserbe et al., 1985) with ${ }^{3} \mathrm{H}-\mathrm{NBI}$ as a ligand probe for adenosine uptake sites demonstrated low densities of adenosine uptake sites, as opposed to high densities of adenosine A1-receptors in areas highly enriched in synapses, such as various hippocampal layers and the molecular layer of cerebellum. An obvious explanation for this gross mismatch could be the existence of adenosine uptake site subtypes. The existence of adenosine receptor subtypes, for instance, probably explains one gross mismatch in the present study: In guinea pig brain, adenosine A1-receptors could not be detected at all in non-neuronal structures such as arteries and choroid plexus, with high adenosine uptake site densities, in good agreement with a membrane binding study describing adenosine A2-receptors in these structures in pig (Kalaria and Harik, 1986b). As in rat brain, major pattern differences were observed between adenosine A1-receptors and uptake sites as labeled by ${ }^{3} \mathrm{H}-\mathrm{NBI}$ in guinea pig brain. In fact, their density patterns were exactly opposite: high ${ }^{3} \mathrm{H}-\mathrm{CHA}$ and low ${ }^{3} \mathrm{H}-\mathrm{NBI}$ binding in cortical structures, and high ${ }^{3} \mathrm{H}-\mathrm{NBI}$ and low ${ }^{3} \mathrm{H}-$ CHA binding densities in basal brain structures. This confirms previous membrane binding studies examining up to 8 regions (Murray and Cheney, 1982; Hammond and Clanachan, 1983). A better correlation could be observed between ${ }^{3} \mathrm{H}-\mathrm{CHA}$ and ${ }^{3} \mathrm{H}$-DPR binding sites, especially in cerebellum with a very similar pattern. In hippocampus, moderate ${ }^{3} \mathrm{H}$-DPR, in addition to very high ${ }^{3} \mathrm{H}-\mathrm{CHA}$ binding, was found, but with an inverse pattern: very high ${ }^{3} \mathrm{H}-\mathrm{CHA}$ binding density in various $\mathrm{CA} 1$ layers and the hilus, but only moderate binding in the molecular layer of the dentate gyrus, as opposed to relatively high ${ }^{3} \mathrm{H}-\mathrm{DPR}$ binding in the molecular layer and relatively lower density in layers of CA1 and the hilus. Thus, even with the use of ${ }^{3} \mathrm{H}-\mathrm{DPR}$ as an additional ligand probe for adenosine uptake sites, discrepancies in receptor and uptake site distribution remained. Adenosine uptake site heterogeneity (as well as adenosine receptor heterogeneity; see Lee and Reddington, 1986) therefore probably does not explain the majority of the previously described discrepancies.

similar in the cerebellum, with high binding in molecular $(M L)$ and Purkinje cell $(P L)$ layers and low densities in the granular cell layer $(G L)$ and lateral cerebellar nucleus $(L C)$. Other structures shown are the rostral part of the nucleus tractus solitarii $(N T S)$ and inferior olivary complex $(I O)$. 
Figure 7. Localization of ${ }^{3} \mathrm{H}-\mathrm{DPR}$ (top), ${ }^{3} \mathrm{H}-\mathrm{NBI}$ (middle), and ${ }^{3} \mathrm{H}-\mathrm{CHA}$ (bottom) binding sites in adjacent coronal sections in the plane of the hippocampus of a pointer dog brain. The distribution of all 3 binding sites is very similar to their distribution in guinea pig brain. The only remarkable difference is their practically identical localization in layers of Ammon's horn $(H)$, and dentate gyrus $(D G)$. Other structures shown are parietal cortex $(C C)$, superior colliculus (superficial gray, $S G$ ), central gray $(C G)$, medial geniculate body $(G B)$, and substantia nigra $(S N)$. Sections labeled with ${ }^{3} \mathrm{H}-\mathrm{NBI}$ and ${ }^{3} \mathrm{H}$ CHA were exposed for 8 weeks together with the corresponding sections in Figure 8 because of the relative low binding densities and the low specific activity of the radiolabels as contrasted to the ${ }^{3} \mathrm{H}$-DPR sections, which were again exposed for 4 weeks. Ligand concentrations were $2.5 \mathrm{nM}$ for ${ }^{3} \mathrm{H}$-DPR, $0.4 \mathrm{nM}$ for ${ }^{3} \mathrm{H}-\mathrm{NBI}$, and $5 \mathrm{~nm}$ for ${ }^{3} \mathrm{H}-\mathrm{CHA}$.
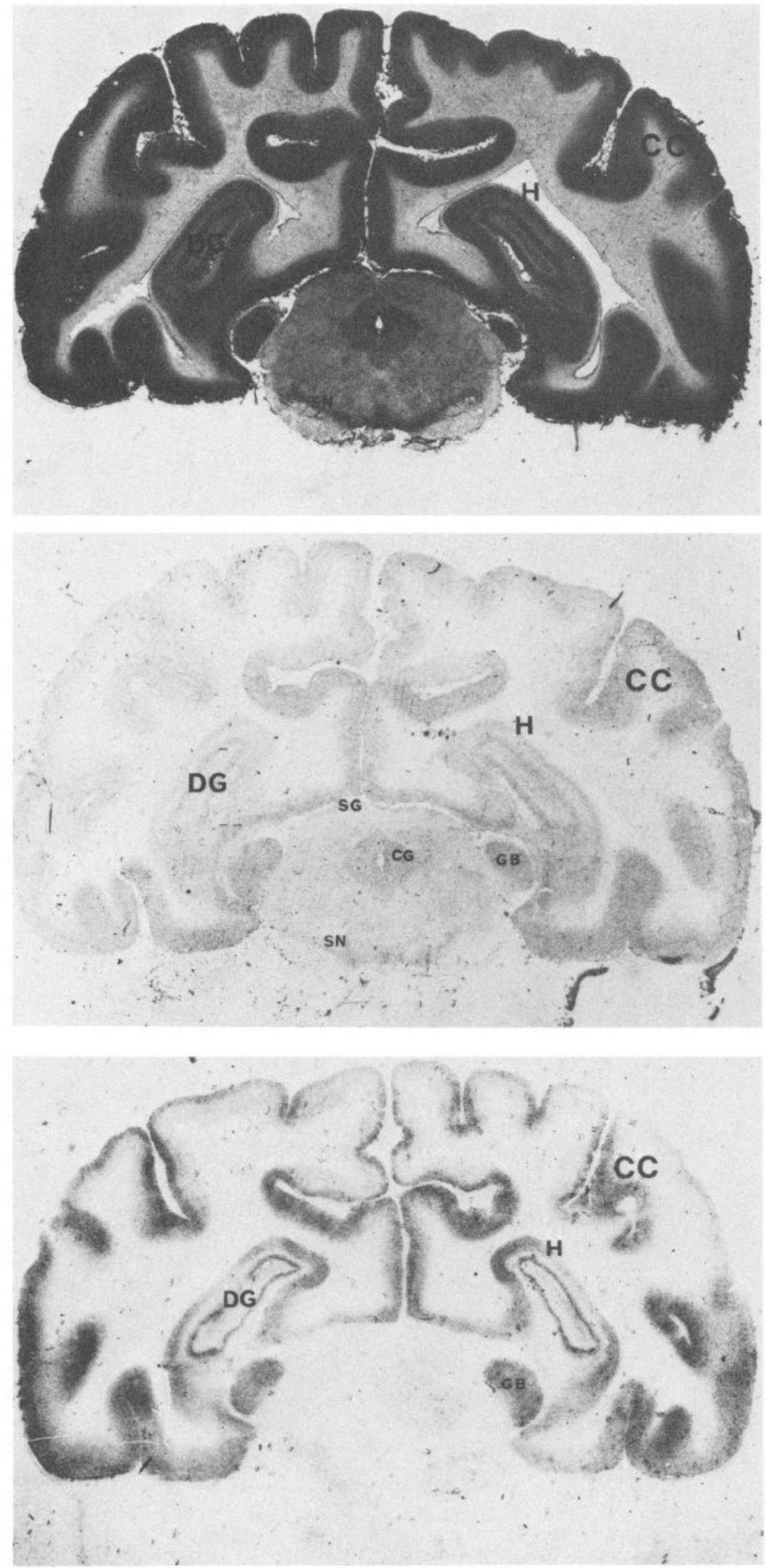

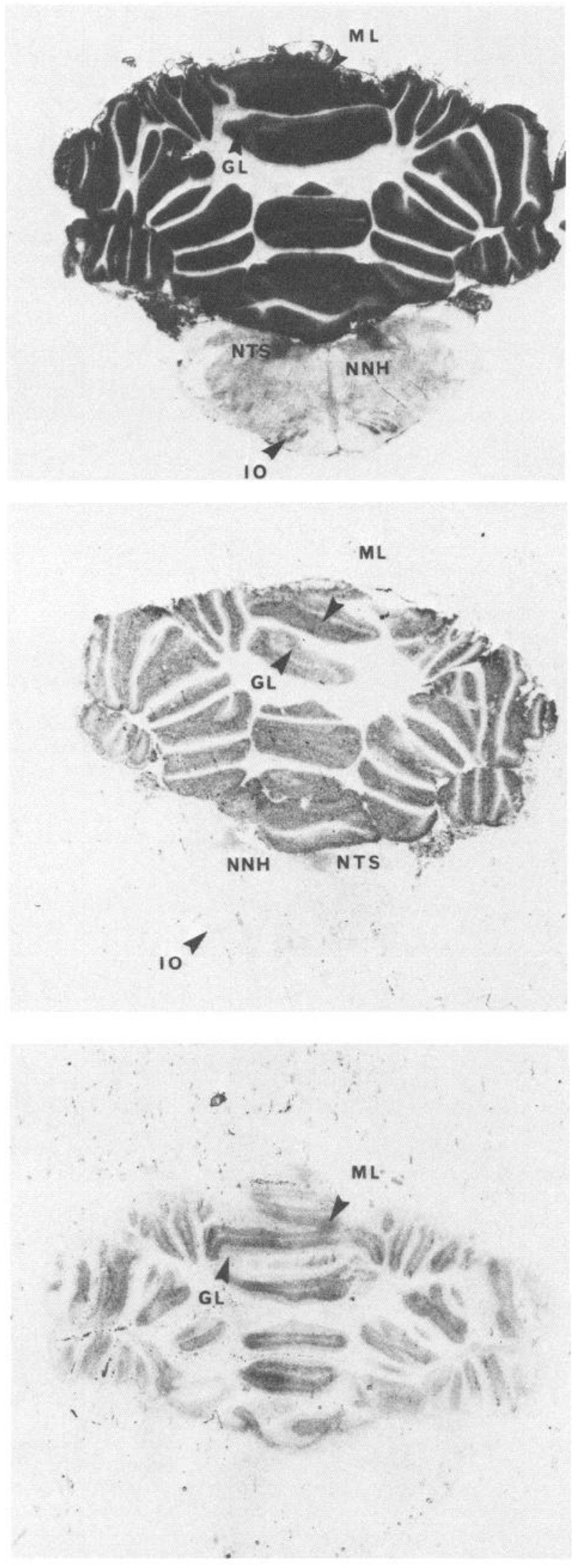

Figure 8. Localization of ${ }^{3} \mathrm{H}-\mathrm{DPR}$ (top), ${ }^{3} \mathrm{H}-\mathrm{NBI}$ (middle), and ${ }^{3} \mathrm{H}-$ CHA (bottom) binding sites in adjacent coronal sections in the plane of the cerebellum of a pointer dog brain. Similar to that of guinea pig is the distribution of ${ }^{3} \mathrm{H}-\mathrm{CHA}$ binding sites, with hardly any labeling in
Adenosine uptake site heterogeneity, as proposed in guinea pig brain, may thus serve as an explanation for some, but not all, of the distribution mismatches previously observed in rat brain between adenosine A1-receptors and adenosine uptake sites as labeled by ${ }^{3} \mathrm{H}-\mathrm{NBI}$. As in guinea pig, NBI has been shown to inhibit less than $50 \%$ of adenosine uptake in rat brain synaptosomes in submicromolar concentrations (Bender et al., 1981), and a recent study of adenosine uptake into rat brain synaptoneurosomes demonstrates a biphasic inhibition of this uptake by NBI (Morgan and Marangos, 1987). Owing to the low affinity of DPR for adenosine uptake sites in rat and mouse brain, however, it cannot be used as a high-affinity ligand probe in these species, as in guinea pig, and the development of new, high-affinity ligand probes for NBI-insensitive uptake sites in these species is required to probe the possibility of adenosine uptake site heterogeneity. In dog brain, no functional data are available at the present time. The inhibition of ${ }^{3} \mathrm{H}-\mathrm{DPR}$ binding to pointer dog prefrontal cortex slices by NBI was not as biphasic as in guinea pig, and a possible lower-affinity ${ }^{3} \mathrm{H}-\mathrm{NBI}$ binding site was not excluded under our experimental conditions because of the limitations of the method. In the autoradiographic experiments, a similar distribution pattern was seen for both adenosine uptake site probes in hippocampus and cerebellum, which could well be explained by the existence of a lower-affinity ${ }^{3} \mathrm{H}-\mathrm{NBI}$ binding site. Also, as opposed to the case of guinea pig and rat, the distribution pattern of ${ }^{3} \mathrm{H}-\mathrm{CHA}$ binding was very similar to that of both uptake site probes, not only in cerebellum, but also hippocampus, which could be partly due to the different cytoarchitecture of dog and rodent hippocampus. The observed species differences clearly caution against drawing any conclusions regarding the adenosine uptake site and its relationship to adenosine Al-receptors from one species to the other. This is in contrast to adenosine Al-receptors themselves, which seem to be well conserved between species (at least among rodents), but similar to 5 'nucleotidase, the distribution of which also varies from rodent to rodent (Lee et al., 1985).

Among areas with both adenosine Al-receptor and uptake sites in guinea pig and pointer dog brain were many structures whose function was to receive and modulate sensory input, such as pyriform cortex, superior colliculus, cochlear nucleus, and nucleus spinalis nervi trigemini, and, on a higher level, the geniculate bodies, various nuclei of amygdala and thalamus, hippocampus, and finally cerebral cortex (sensory part) and cerebellar cortex. This suggests a role for adenosine in the regulation of sensory input, which, in protecting the brain from "overexcitation" in the context of Newby's concept of adenosine as a retaliatory metabolite (Newby, 1984), may well be its main physiological role. The nature of this adenosinergic neuromodulation could be considerably influenced by the relative density of receptors (potential for neurodepression by adenosine) and uptake sites (capacity for uptake and inactivation of adenosine). The discrepancy between receptor and uptake site density in structures like hypothalamus, area postrema, and nucleus trac-

brain stem structures and higher binding density in the molecular layer $(M L)$ than in the granular cell layer $(G L)$. In contrast to the situation in guinea pig brain and similar to the situation in pointer dog forebrain (Fig. 7) both ${ }^{3} \mathrm{H}-\mathrm{DPR}$ and ${ }^{3} \mathrm{H}-\mathrm{NBI}$ binding show a similar pattern to that of ${ }^{3} \mathrm{H}-\mathrm{CHA}$ and denser labeling in the cerebellum than in various brain stem structures, such as nucleus tractus solitarii (NTS), nucleus nervi hypoglossi $(N N H)$, and the inferior olivary complex $(I O)$. 
tus solitarii, with high uptake site density, may thus find an explanation in the need to keep adenosine concentrations modulating vital autonomous and endocrine functions in these areas via relatively few receptors, independent from increases in plasma adenosine levels, while the moderate uptake site density in hippocampus may indicate a need for a relatively high extracellular adenosine concentration to modulate excitatory hippocampal neurons via an extraordinarily high number of reccptors.

Several enzymes involved in adenosine metabolism, such as 5 'nucleotidase (Scott, 1967), adenosine deaminase (Nagy et al., 1984), and S-adenosylhomocysteine hydrolase (Patel and Tudball, 1986), have been localized in brain with histochemical and immunocytochemical techniques, and have been suggested as markers for adenosinergic neurons. Parallels in the distribution of ${ }^{3} \mathrm{H}-\mathrm{NBI}$ binding sites and in the distribution of adenosine deaminase immunoreactivity in rat brain have been observed (Nagy et al., 1985). Recently, the distribution of adenosine itself has been described in rat brain, using a polyclonal antibody (Braas et al., 1986). It has been found colocalized with adenosine A1-receptors to retinal ganglion cells, and a good, but not complete, correlation with adenosine uptake sites as labeled by ${ }^{3} \mathrm{H}$ NBI has been reported (Braas et al., 1987). The similarities and discrepancies in the distribution of adenosine uptake sites, as labeled by ${ }^{3} \mathrm{H}-\mathrm{NBI}$, and these various markers in rat brain with regard to potential implications for adenosinergic neuromodulation have been discussed (Braas et al., 1986). However, owing to the different resolution limits, comparisons between studies employing radioligand probes and antibodies are rather difficult. Possibly only for this reason, the remarkable concentrations observed for adenosine in circumscript motor nuclei do not find any correspondence in observations from radioligand studies (exception: moderate adenosine uptake site density in nucleus nervi hypoglossi). The availability of ${ }^{3} \mathrm{H}$-DPR as ligand probe for NBI-insensitive adenosine uptake sites thus resolves only few of the observed discrepancies. The only area in which a similar distribution pattern for most of these putative markers for a postulated adenosinergic system has now been established is cerebellum: adenosine Al-receptors, adenosine itself, adenosine uptake sites (especially when labeled by ${ }^{3} \mathrm{H}$-DPR), 5'nucleotidase, and, with some restrictions, also 5'adenosylhomocysteine hydrolase have been described in descending density in the Purkinje cell layer, the molecular layer, and the granular cell layer of cerebellar cortex. Interpretation of the observed pattern similarities and discrepancies of these markers in relation to adenosine uptake sites with regard to potential implications for adenosinergic neuromodulation is necessarily even more complex than the interpretation of the distribution pattern of adenosine uptake sites and receptors, not just for the abovementioned technical reasons, but also because the enzymes concerned and adenosine itself are probably involved in a range of cell processes besides modulation of neurotransmission (sce Braas et al., 1986). Nevertheless, these markers, in addition to ligand probes for adenosine receptors and uptake sites, such as ${ }^{3} \mathrm{H}-$ DPR, will probably prove to be useful tools in future studies defining the anatomical localization of adenosinergic neuromodulation in human brain (Fastbom et al., 1986; Braas et al., 1987).

\section{References}

Barberis, C., A. Minn, and J. Gayet (1981) Adenosine transport in guinea pig synaptosomes. J. Neurochem. 36: 347-354.
Belt, J. A. (1983) Heterogeneity of nucleoside transport in mammalian cells. Mol. Pharmacol. 18: 40-44.

Bender, A. S., P. H. Wu, and J. W. Phillis (1980) The characterization of $\left[{ }^{3} \mathrm{H}\right]$ adenosine uptake into rat cerebral cortical synaptosomes. $\mathbf{J}$. Neurochem. 35: 629-640.

Bender, A. S., P. H. Wu, and J. W. Phillis (1981) Some biochemical properties of the rapid adenosine uptake system in rat brain synaptosomes. J. Neurochem. 37: 1282-1290.

Bisserbe, J. C., J. Patel, and P. J. Marangos (1985) Autoradiographic localization of adenosine uptake sites in rat brain using $\left[{ }^{3} \mathrm{H}\right]$ nitrobenzylthioinosine. J. Neurosci. 5: 544-550.

Bisserbe, J. C., J. Deckert, and P. J. Marangos (1986) Autoradiographic localization of adenosine uptake sites in guinea pig brain using $\left[{ }^{3} \mathrm{H}\right]$ dipyridamole. Neurosci. Lett. $66: 341-345$.

Braas, K. M., A. C. Newby, V. S. Wilson, and S. H. Snyder (1986) Adenosine-containing neurons in the brain localized by immunocytochemistry. J. Neurosci. 6: 1952-1961.

Braas, K. M., M. A. Zarbin, and S. H. Snyder (1987) Endogenous adenosine and adenosine receptors localized to ganglion cells of the retina. Proc. Natl. Acad. Sci. USA 84: 3906-3910.

Bradford, M. W. (1976) Rapid and sensitive method for the quantification of microgram quantities of protein utilizing the principle of protein-dye binding. Anal. Biochem. 72: 248-254.

Bruns, R. F., J. W. Daly, and S. H. Snyder (1980) Adenosine receptors in brain membranes: Binding of $N^{6}$-cyclohexyl $\left({ }^{3} \mathrm{H}\right)$ adenosine and 1,3 diethyl-8-( $\left.{ }^{3} \mathrm{H}\right)$ phenylxanthine. Proc. Natl. Acad. Sci. USA 77: 55475551 .

Cass, C. E., and A. R. P. Paterson (1972) Mediated transport of nucleosides in human erythrocytes. J. Biol. Chem. 247: 3314-3320.

Davies, L. P., and J. W. Hambley (1983) Diazepam inhibition of adenosine uptake in the CNS: Lack of effect on adenosine kinase. Gen. Pharmacol. 14: 307-309.

Davies, I. P., and J. W. Hambley (1986) Regional distribution of adenosine uptake in guinea pig brain slices and the effect of some inhibitors: Evidence for nitrobenzylthioinosine-sensitive and insensitive sites? Neurochem. Int. 8: 103-108.

Dunwiddie, T. V. (1985) The physiological role of adenosine in the nervous system. In International Review of Neurobiology, vol. 27, J. R. Smythies and R. J. Bradley, eds., pp. 63-139, Academic, New York.

Ebersolt, C., J. Premont, A. Prochiantz, M. Perez, and J. Bockaert (1983) Inhibition of brain adenylate cyclase by $A 1$ adenosine receptors; pharmacological characteristics and localization. Brain Res. 267: 123-129.

Fastbom, J., A. Pazos, A. Probst, and J. M. Palacios (1986) Adenosine A1-receptors in human brain: Characterization and autoradiographic visualization. Neurosci. Lett. 65: 127-132.

Geiger, J. D., and J. Nagy (1984) Heterogenous distribution of adenosine transport sites labelled by $\left[{ }^{3} \mathrm{H}\right]$ nitrobenzylthioinosine: $\mathrm{An}$ autoradiographic and membrane binding study. Brain Res. Bull. 13 . $657-666$.

Gochee, C., W. Rasband, and L. Sokoloff (1980) Computerized densitometry and colour coding of $\left[{ }^{14} \mathrm{C}\right]$ deoxyglucose autoradiographs. Ann. Neurol. 7: 359-370.

Goodman, R. R., and S. H. Snyder (1982) Autoradiographic localization of adenosine receptors in rat brain using $\left[{ }^{3} \mathrm{H}\right]$ cyclohexyladenosine. J. Neurosci. 2: 1230-1241.

Hammond, J. R., and A. S. Clanachan (1983) Distribution of nucleoside transport sites in guinea pig brain. J. Pharm. Pharmacol. 35: 117118.

Hammond, J. R., and A. S. Clanachan (1984) [ $\left.{ }^{3} \mathrm{H}\right]$ Nitrobenzylthioinosine binding to the guinea pig CNS nucleoside transport system: A pharmacological characterization. J. Neurochem. 43: 15821592.

Hammond, J. R., and A. S. Clanachan (1985) Species differences in the binding of $\left[{ }^{3} \mathrm{H}\right]$ nitrobenzylthioinosine in the nucleoside transporter system in mammalian central nervous system membranes: Evidence for interconvertible conformations of the binding site/transporter complex. J. Neurochem. 45: 527-535.

Herkenham, M., and C. B. Pert (1982) Light-microscopic localization of opiate receptors: A general autoradiographic method which preserves tissue quality. J. Neurosci. 2: 1129-1149.

Huang, M., and J. W. Daly (1974) Adenosine-elicited accumulation of cyclic-AMP in brain slices: Potentiation by agents which inhibit uptake of adenosine. Life Sci. 14: 489-503. 
Jarvis, S. M., and J. D. Young (1980) Nucleoside transport in human and sheep erythrocytes. Biochem. J. 190: 377-383.

Jarvis, S. M., and J. D. Young (1981) Extraction and partial purification of the nucleoside transport system from human erythrocytes based on the assay of nitrobenzylthioinosine-binding activity. Biochem. J. 194: 331-339.

Kalaria, R. N., and S. I. Harik (1986a) Nucleoside transporter of cerebral microvessels and choroid plexus. J. Neurochem. 47: 18491856.

Kalaria, R. N., and S. I. Harik (1986b) Adenosine receptors of cerebral microvesscls and choroid plexus. J. Ccr. Blood Flow Mctab. 6: 463470 .

Kolossa, N., and K. Pfleger (1975) Adenosine uptake by erythrocytes of man, rat and guinea pig and its inhibition by hexobendine and dipyridamole. Biochem. Pharmacol. 24: 154-156.

Lee, K. S., and M. Reddington (1986) Autoradiographic evidence for multiple CNS binding sites for adenosine derivatives. Neuroscience 19: 535-549.

Lee, K. S. P. Schubert, M. Reddington, and G. W. Kreutzberg (1985) The distribution of 5 'nucleotidase and adenosine A1-receptors: Evidence for diversification and conservation in the hippocampi of several commonly employed experimental animals. Acta Histochem. 31: $47-51$.

Lewis, M. E., J. Patel, S. Moon-Edley, and P. J. Marangos (1981) Autoradiographic visualization of rat brain adenosine receptors using $N^{6}$-cyclohexyl $\left({ }^{3} \mathrm{H}\right)$ adenosine. Eur. J. Pharmacol. 73: 109-1 10.

Londos, C., D. M. F. Cooper, and J. Wolff (1980) Subclasses of external adenosine receptors. Proc. Natl. Acad. Sci. USA 77: 2551-2554.

Luparello, T. J. (1967) Stereotaxic Atlas of the Forebrain of the Guinea Pig, Williams \& Wilkins, Baltimore, MD.

Marangos, P. J., and J. Deckert (1987) [ $\left.{ }^{3} \mathrm{H}\right]$ Dipyridamole binding to guinea pig membranes, possible heterogeneity of central adenosine uptake sites. J. Neurochem. 48: 1231-1237.

Marangos, P. J., J. Patel, R. Clark-Rosenberg, and A. M. Martino (1982) $\left[{ }^{3} \mathrm{H}\right]$ Nitrobenzylthioinosine binding as a probe for the study of adenosine uptake sites in brain. J. Neurochem. 39: 184-191

Marangos, P. J., M. Houston, and P. Montgomery (1985) [ $\left.{ }^{3} \mathrm{H}\right]$ Dipyridamole: A new ligand probe for brain adenosine uptake sites. Eur. J. Pharmacol. 117: 393-394.

Morgan, P. F., and P. J. Marangos (1987) Comparative aspects of nitrobenzylthioinosine and dipyridamole inhibition of adenosine accumulation in rat and guinea pig synaptoneurosomes. Neurochem. Int. 11: 339-346.

Murray, T. F., and D. L. Cheney (1982) Neuronal localization of $N^{6}-$ cyclohexyladenosine binding sites in rat and guinea pig brain. Neuropharmacology 21: 575-580.

Nagy, J. I., L. A. Bella, M. Buss, and P. E. Daddona (1984) Immunohistochemistry of adenosine deaminase. Implications for adenosine neurotransmission. Science 224: 166-168.

Nagy, J. I., J. D. Geiger, and P. E. Daddona (1985) Adenosine uptake sites in rat brain: Identification using $\left[{ }^{3} \mathrm{H}\right]$ nitrobenzylthioinosine and colocalization with adenosine deaminase. Neurosci. Lett. 55: 47-53.

Newby, A. C. (1984) Adenosine and the concept of retaliatory metabolites. Trends Biol. Sci. 9: 42-44.

Patel, B. T., and N. Tudball (1986) Localization of $S$-adenosylhomocysteine hydrolase and adenosine deaminase immunoreactivites in rat brain. Brain Res. 370: 250-264.

Patel, J., P. J. Marangos, and J. P. Boulenger (1984) Adenosine: Its action and sites of action in the CNS. In Brain Receptor Methodologies, pt. B, P. J. Marangos, I. Campbell, and R. M. Cohen, eds., pp. 297-325, Academic, New York

Paterson, A. R. P., E. Y. Lau, E. Dahlig, and C. E. Cass (1980) A common basis for inhibition of nucleoside transport by dipyridamole and nitrobenzylthioinosine? Mol. Pharmacol. 18: 40-44.

Paxinos, G., and C. Watson (1982) The Rat Brain in Stereotaxic Coordinates, Academic, New York

Penney, J. B., K. Frey, and A. B. Young (1981) Quantitative autoradiography of neurotransmitter receptors using tritium-sensitive film. Eur. J. Pharmacol. 72: 248-252.

Phillis, J. W., and P. H. Wu (1983) Nitrobenzylthioinosine inhibition of adenosine uptake in guinea pig brain. J. Pharm. Pharmacol. 35 540.

Pickard, M. A., R. R. Brown, B. Paul, and A. R. P. Paterson (1973) Binding of the nucleoside transport inhibitor 4-nitrobenzylthioinosine to erythrocyte membranes. Can. J. Biochem. 51: 666-672.

Plagemann, P. G. W., and R. M. Wohlhueter (1984) Nucleoside transport in cultured mammalian cells. Biochim. Biophys. Acta 773: 3952.

Sanderson, G., and C. N. Scholfield (1986) Effects of adenosine uptake blockers and adenosine on evoked potentials of guinea pig olfactory cortex. Pfluegers Arch. 406: 25-30.

Schwabe, U., and T. Trost (1980) Characterization of adenosine receptors in rat brain by $(-)\left[{ }^{3} \mathrm{H}\right]$ phenylisopropyladenosine. NaunynSchmiedebergs Arch. Pharmacol. 321: 84-87.

Scott, T. G. (1967) The distribution of 5 'nucleotidase in the brain of the mouse. J. Comp. Neurol. 129: 97-113.

Singer, M. (1962) The Brain of the Dog in Sections, Saunders, Philadelphia, PA

Stafford, A. (1966) Potentiation of adenosinc and the adcninc nuclcotides by dipyridamole. Br. J. Pharmacol. Chemother. 28: 218-227.

van Calker, D., M. J. Mueller, and B. Hamprecht (1979) Adenosine regulates via two different types of receptors, the accumulation of cyclic AMP in cultured brain cells. J. Neurochem. 33: 999-1 105.

Verma, A., and P. J. Marangos (1985) Nitrobenzylthioinosine binding to brain: An interspecies study. Life Sci. 36: 283-290.

Wojcik, W. J., and N. H. Neff (1983) Differential location of adenosine $\mathrm{A} 1$ and $\mathrm{A} 2$ receptors in striatum. Neurosci. Lett. 41: 55-60.

Yeung, S. M. H., and R. D. Green (1984) $\left[{ }^{3} \mathrm{H}\right] 5^{\prime}-N$-ethylcarboxamide adenosine binds to both $\mathrm{Ra}$ and $\mathrm{Ri}$ adenosine receptors in rat striatum. Naunyn-Schmiedebergs Arch. Pharmacol. 325: 218-225. 